\title{
Storiform collagenoma: case report
}

\author{
Colagenoma estoriforme: relato de caso \\ Guilherme Flosi Stocchero ${ }^{1}$
}

\begin{abstract}
Storiform collagenoma is a rare tumor, which originates from the proliferation of fibroblasts that show increased production of type-I collagen. It is usually found in the face, neck and extremities, but it can also appear in the trunk, scalp and, less frequently, in the oral mucosa and the nail bed. It affects both sexes, with a slight female predominance. It may be solitary or multiple, the latter being an important marker for Cowden syndrome. It presents as a painless, solid nodular tumor that is slow-growing. It must be considered in the differential diagnosis of other well-circumscribed skin lesions, such as dermatofibroma, pleomorphic fibroma, sclerotic lipoma, fibrolipoma, giant cell collagenoma, benign fibrous histiocytoma, intradermal Spitz nevus and giant cell angiohistiocytoma.
\end{abstract}

Keywords: Collagen; Hamartoma; Skin neoplasms; Fibroma; Skin; Case reports

\section{RESUMO}

0 colagenoma estoriforme é um tumor raro originado a partir da proliferação de fibroblastos com produção aumentada de colágeno tipo I. É encontrado mais frequentemente na face, pescoço e extremidades, podendo aparecer no tronco, couro cabeludo e, raramente, na mucosa oral e leito subungueal. Afeta ambos os gêneros, com discreta predominância em mulheres. Pode ser solitário ou múltiplo, sendo que, neste caso, é um importante indicador da presença de síndrome de Cowden. Apresenta-se como tumor sólido, nodular, de crescimento lento e indolor. Deve constar como diagnóstico diferencial de tumores cutâneos bem delimitados, como dermatofibroma, fibroma pleomórfico, lipoma esclerótico, fibrolipoma, colagenoma de células gigantes, histiocitoma fibroso benigno, nevo de Spitz intradérmico e angioistiocitoma de células gigantes.

Descritores: Colágeno; Hamartoma; Neoplasias cutâneas; Fibroma; Pele; Relatos de casos

\section{INTRODUCTION}

Storiform collagenoma or sclerotic fibroma is a rare benign skin tumor that usually affects young adults and middle-age individuals of both sexes. This tumor is slightly predominant in women. Storiform collagenoma appears as a small papule or solid fibrous nodule. It is well-circumscribed, pink, whitish or skin color, painless and of slow-growing. This tumor is often found in face and limbs, but it can also appears in the chest, scalp and, rarely, in oral mucosa and nail bed. Storiform collagenoma often appears as single tumor, and the occurrence of multiple tumors is an important indication of Cowden syndrome, which is a heritage genodermatosis of autosomal dominant condition. ${ }^{(1-4)}$ Storiform collagenoma has as differential diagnosis other well-circumscribed skin tumors such as dermatofibroma, pleomorphic fibroma, sclerotic lipoma, fibrolipoma, giant cell collagenoma, benign fibrous histiocytoma, intradermal Spitz nevus and giant cell angiohistiocytoma. ${ }^{(5-8)}$

\section{CASE REPORT}

We report a case of a 36-year-old man, white, who was a cleaning assistant, born in Aracajú (SE) and lived in São Paulo (SP) for 15 years. He complained of mass appearance on his right shoulder, at least 2 years ago, with slow-growing, painless and without sings of inflammation or secretion exit. The patient denied previous trauma where the mass was located, appearance of other masses, comorbidities, personal or family previous history of diseases, alcohol abuse, smoking and use of illegal drugs.

1 Instituto de Cirurgia Plástica Santa Cruz, São Paulo, SP, Brazil.

Corresponding author: Guilherme Flosi Stocchero - Instituto de Cirurgia Plástica Santa Cruz, Rua Santa Cruz, 398 - Vila Mariana - Zip code:04122-000 - São Paulo, SP, Brazil - Phone: ( 55 11) 5080-2196 E-mail: guilherme@vivermelhor.com.br

Receveid on: July 7, 2013 - Accepted on: Dec 4, 2013

DOI:10.1590/\$1679-45082015RC2907 
At physical examination, he had nodular injury in suprascapular region, well-delimited, pink measuring $1.5 \mathrm{~cm}$ in diameter, fibrotic consistency and non-painful on palpation (Figure 1).

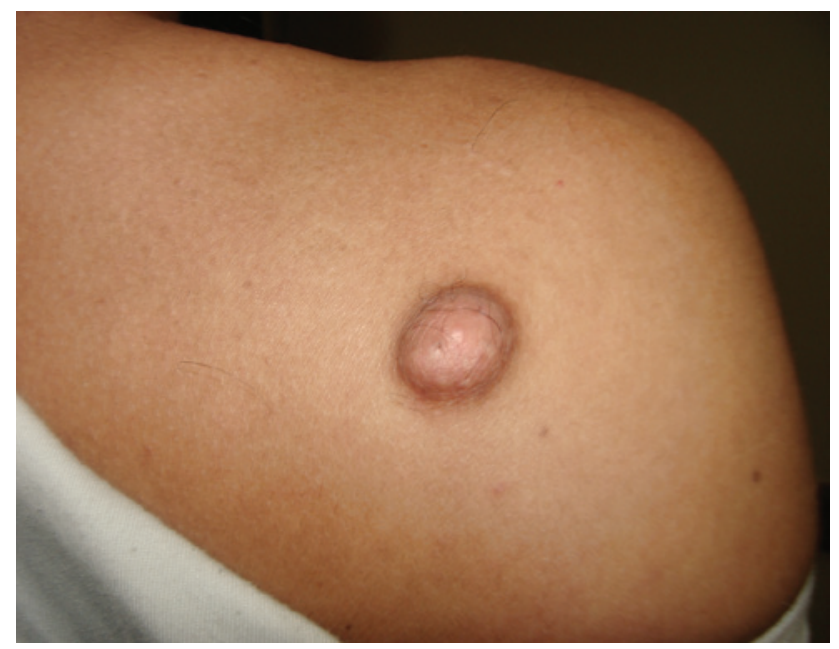

Figure 1. Aspect of the injury before surgery

The patient underwent skin fuse exeresis containing an injury under local anesthesia with lidocaine, followed by primary simple suture using black Nylon $4.0 \mathrm{~mm}$ and bandage with sterile gauze and microporous tape. Histopathological study of injury was done. The patient was advised to clean the surgical wound daily using aqueous chlorhexidine and change bandage every day. After 14 days, stitches were removed and the scar evolved satisfactory after the surgery (Figure 2).

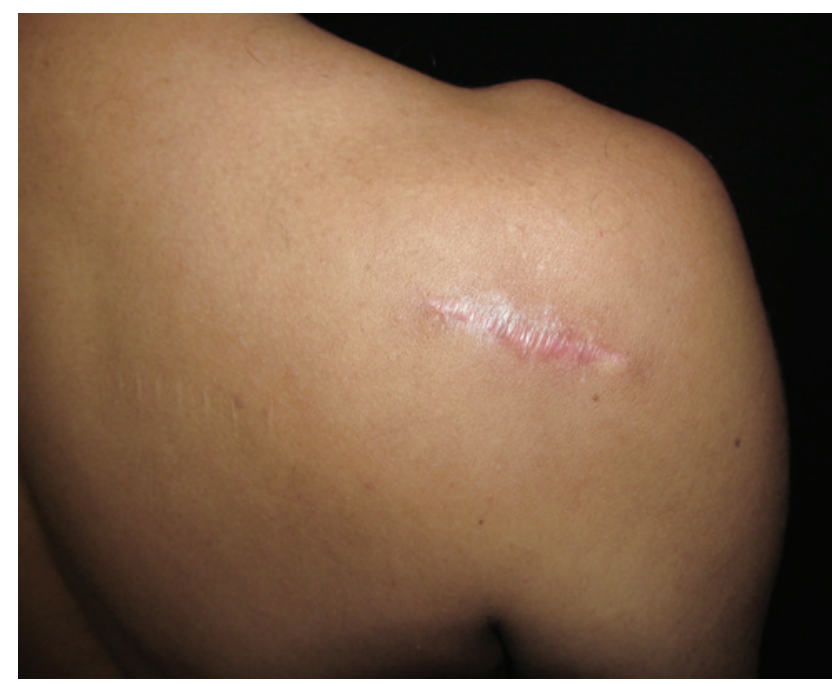

Figure 2. Aspect of operated site (2 months) after surgery
Histopathological exam of injury revealed a welldefined nodule formation characterized by hypocellular collagen proliferation with irregularly arranged collagen fibrous. Presence of cells with poor-defined cytoplasm and both oval and elongated nuclei. Nodule was surrounded by preserved dermis and epidermis without significant histological changes. The injury was totally removed and no histological signs of malignancy were found. Microscopy findings indicated the diagnosis of storiform collagenoma.

\section{DISCUSSION}

Storiform collagenoma is a benign tumor that was first described by Weary et al., ${ }^{(9)}$ in the tongue of a patient with Cowden syndrome, a heritage genodermatosis of autosomal dominant condition that is associated with mucocutaneous injuries such as multiple facial trichilemmoma, verrucous papule in oral mucous, keratosis papule in digital pulps and increase the development of breast cancer and thyroid cancer. After the original description, other authors described the occurrence of storiform collagenoma on the face, palm and plantar region of patients with Cowden syndrome..$^{(10,11)}$ Whether this tumor is hamartoma or truly fibrocystic neoplasm stills unknown. ${ }^{(12,13)}$

Rapini e Golitz ${ }^{(1)}$ were the first authors to described the isolated injury without associated it to a syndrome. Their study included 11 patients with solitary storiform collagenoma in several parts of the body and who did not present any sings of Cowden syndrome.

Requena et al. ${ }^{(4)}$ reviewed the literature and concluded that the presence of multiple storiform collagenoma constitutes a skin marker of Cowden syndrome and such indication can help early diagnosis of genodermatosis. The presence of solitary tumor does not guarantee the diagnosis of Cowden syndrome. However, according to Al-Daraji et al. ${ }^{(14)}$ even the finding of isolated storiform collagenoma must provide detailed clinical investigation of the patient in order to find others sings that may indicate the presence of Cowden syndrome, particularly because storiform collagenoma can be first clinical evidence of genodermatosis.

From histopathological point of view, the injury is typical and consists of fibroma primary formed by thick collagen fibers and scarcity of fibroblasts. Collagen fibers are irregular or "onion rings" like arranged. ${ }^{(5)}$

Immunohistochemistry shows that storiform collagenoma usually present positivity for CD34 and vimentin, but negativity for neurofilaments, S-100, neuron-specific enolase, carcinoembryonic antigen, epithelial membrane antigen, high molecular weight keratin and cytokeratin. 
Staining of 13a factor is positive for sparse dendritic cells, which can be useful in dermatofibroma differential diagnosis that shows diffuse positivity along the injury. ${ }^{(15)}$ Diagnosis suggested was fibrocystic cancer with abnormal regulation of production and process of type I collagen. ${ }^{(16)}$

\section{CONCLUSION}

Storiform collagenoma is a rare, benign tumor that can be found in any part of the body and oral mucous. Standard treatment is recession of the free margins. This tumor solitary occurrence is more frequent and, once the histopathological diagnosis is confirmed, no treatment or further investigation is generally required. However, the finding of multiple storiform collagenoma in a patient requires further investigation due to the likelihood of Cowden syndrome diagnosis, both in the patient and his/her family because this is a genetic syndrome. Despite the low incidence of storiform collagenoma due to its clinical presentation, it must be considered in the differential diagnosis of well-delimited tumors such as dermatofibroma, pleomorphic fibroma, sclerotic lipoma, fibrolipoma, giant cell collagenoma, benign fibrous histiocytoma, intradermal Spitz nevus and giant cell angiohistiocytoma.

\section{REFERENCES}

1. Rapini RP, Golitz LE. Sclerotic fibromas of the skin. J Am Acad Dermatol. 1989;20(2 Pt 1):266-71.

2. Lee JH, An JS, Lee ES, Kwon SY, Kim YS. Comparison of sporadic sclerotic fibroma and solitary fibrous tumor in the oral cavity. Yonsei Med J. 2007:48(3):535-9.

3. Tosti A, Cameli N, Peluso AM, Fanti PA, Peserico A. Storiform collagenoma of the nail. Cutis. 1999;64(3):203-4.

4. Requena L, Gutiérrez J, Sánchez Yus E. Multiple sclerotic fibromas of the skin. A cutaneous marker of Cowden's disease. J Cutan Pathol. 1992;19(4):346-51. Review.

5. Izquierdo MJ, Pastor MA, Carrasco L, Requena C, Soguero ML, Moreno C, et al. [Sclerotic fibroma with multinucleated giant cells.] Actas Dermosifiliogr. 2001;92(9):419-21. Spanish.

6. Zelger BG, Zelger B, Steiner H, Rütten A. Sclerotic lipoma: lipomas simulating sclerotic fibroma. Histopathology.1997;31(2):174-81.

7. Rudolph P, Schubert C, Harms D, Parwaresch R. Giant cell collagenoma: a benign dermal tumor with distinctive multinucleated cells. Am J Surg Pathol. 1998;22(5):557-63.

8. Brito H, Pereira EM, Reis-Filho JS, Maeda SA. Giant cell collagenoma: case report and review of the literature. J Cutan Pathol. 2002;29(1):48-51.

9. Weary PE, Gorlin RJ, Gentry WC Jr, Comer JE, Greer KE. Multiple hamartoma syndrome (Cowdens disease). Arch Dermatol. 1972;106(5):682-90.

10. Brownstein MH, Mehregan AH, Bikowskis JB, Lupulescu A, Patterson JC. The dermatopathology of Cowden's syndrome. Br J Dermatol. 1979;100(6):667-73.

11. Starink TM, Meijer CJ, Brownstein MH. The cutaneous pathology of Cowden's disease: new findings. J Cutan Pathol. 1985;12(2):83-93.

12. Donati P, Amantea A, Carducci M, Balus L. Sclerotic (hypocellular) fibromas of the skin. Br J Dermatol. 1991;124(4):395-6.

13. Lo WL, Wong CK. Solitary sclerotic fibroma. J Cutan Pathol. 1990;17(5):269-73.

14. Al-Daraji WI, Ramsay HM, Ali RB. Storiform collagenoma as a clue for Cowden disease or PTEN hamartoma tumour syndrome. J Clin Pathol. 2007:60(7):840-2.

15. Bhambri A, Del Rosso J0. Solitary sclerotic fibroma. J Clin Aesthet Dermatol. 2009;2(6):36-8.

16. Shitabata PK, Crouch EC, Fitzgibbon JF, Swanson PE, Adesokan PN, Wick MR. Cutaneous sclerotic fibroma. Immunohistochemical evidence of a fibroblastic neoplasm with ongoing type I collagen synthesis. Am J Dermatopathol. 1995;17(4):339-43. 